\title{
Hydrogeological Properties of Geological Elements in Geological Model around KURT
}

\author{
KURT 지역에서 지질모델 요소에 대한 수리지질특성 \\ Kyung Woo Park1), Kyung Su Kim, Yong Kwon Koh and Jong Won Choi \\ Korea Atomic Energy Research Institute, 989-111 Daedeok-Daero, Yuseong-Gu, Daejeon \\ 박경우1), 김경수, 고용권, 최종원 \\ 한국원자력연구원, 대전시 유성구 대덕대로 989 번길 111
}

(Received August 16, 2012 / Revised September 14, 2012 / Approved September 15, 2012)

\begin{abstract}
To develop site characterization technologies for a radioactive waste disposal research in KAERI, the geological and hydrogeological investigations have been carried out since 1997. In 2006, the KURT (KAERI Underground Research Tunnel) was constructed to study a solute migration, a microbiology and an engineered barrier system as well as deeply to understand geological environments in in-situ condition. This study is performed as one of the site characterization works around KURT. Several investigations such as a lineament analysis, a borehole/tunnel survey, a geophyscial survey and logging in borehole, were used to construct the geological model. As a result, the geological model is constructed, which includes the lithological model and geo-structural model in this study. Moreover, from the results of the in-situ hydraulic tests, the hydrogeological properties of elements in geological model were evaluated.
\end{abstract}

Key words : Site characterization technologies, KAERI Underground Research Tunnel, Geological model, Hydrogeological properties

\section{요 약}

방사성폐기물처분을 위한 부지특성평가 기술 개발을 위해 지질특성조사와 수리지질특성조사가 1997년부터 지표기반 조사, 시추공 조사, 터널조사를 포함하여 수행되었다. 특히, 2006년에는 지하처분연구시설 (KURT, KAERI Underground Research Tunnel)을 건설하여 지하 환경에서 심부지질환경에 대한 연구 뿐 만 아니라 용 질이동특성, 미생물특성, 공학적 방벽 시스템 연구 등 방사성폐기물처분을 위한 다양한 수행하고 있다. 본 연 구는 한국원자력연구원내 건설된 지하처분연구시설 주변 지역을 연구지역으로 부지특성모델 구축의 일환으로 수행되었다. 연구지역의 지질모델구축을 위해 선형구조분석, 시추공/터널 조사, 지구물리탐사를 포함한 다양 한 연구를 수행하여, 암질모델과 지질구조모델을 구축하였으며, 현장수리시험의 결과를 이용하여 암질모델과 지질구조모델을 포함한 지질모델에 입력된 요소에 대한 수리지질특성이 평가되었다.

중심단어 : 방사성폐기물처분, 지하처분연구시설, 지질모델, 수리지질특성

1) Corresponding Author. E-mail : woosbest@kaeri.re.kr 


\section{I. 서 론}

원자력 발전의 부산물인 사용후 핵연료의 안전한 관리는 국가 원자력에너지의 연속적이고 안전한 이용을 위해 반드 시 필요하다. 이러한 사용후 핵연료의 안전한 관리는 저장, 저장기간이 경과한 후 사용후 핵연료를 처분 지역까지 수송, 최종 처분으로 요약할 수 있는데, 현재 국내에서 사용후 핵 연료의 저장은 발생 지역에서 습식저장 방법을 이용하고 있 으며 일정한 기간 동안 저장한 후, 최종적으로 처분하여 안 전하게 관리하게 된다. 사용후 핵연료의 최종 처분과 관련하 여 우주처분, 해양처분, 극지처분, 지층처분 등 다양한 방법 이 제안되었는데, 현재에는 자국 내 심지층에 사용후 핵연료 를 처분하는 심지층 처분개념이 일반적이다. 따라서 사용후 핵연료 관리의 최종 단계인 심지층 처분을 위해 자국내 처분 대상 영역에서 지질 환경에 대한 연구가 필수적이다.

방사성폐기물의 심지층 처분과 관련하여, 처분 대상 심도 에 대한 전반적인 지질 환경을 조사는 것을 부지특성조사라 정의하고, 이에 대한 연구는 방사성 물질의 격리 기능과 지 연 기능을 담당하는 처분 심도의 지질학적, 수리지질학적, 지구화학적, 지질 역학적 특성에 대한 부분으로 구분할 수 있다. 이 중 지질학적 특성에 대한 연구는 처분 영역의 모암 에 대한 광물 - 암석학적 특성, 단층 및 단열대에 지질 구조 적 특성 등 제반 지질환경 특성을 포함한다. 수리지질학적 특성 연구는 처분 지역의 지표 수문 특성, 천부 영역과 처분 심도의 지하수 유동 및 용질의 이동과 관련된 수리지질학적 특성을 포함한다. 지질 및 수리지질학적 측면에서 고려해 볼 때, 사용후 핵연료를 위한 방사성폐기물처분장으로 적합한 환경은 처분 심도에서의 지질이 구조적으로 안정한 지괴에 위치해야 하고, 상당 기간 지표 기후 변화를 예측하여 처분 심도에서 이로부터 영향을 미치지 않아야 한다. 또한, 처분 심도에서 지하수의 유동이 아주 적거나 없어야 하며, 처분장 에서 생태계에 이르기까지 지하수의 유동로의 역할을 할 잠 재적 투수성 지질구조 (단열대, 단층)가 없어 지하수의 유동 이 처분 심도 상부의 암반층과 격리된 수리지질학적 측면도 고려되어야 한다.

본 논문은 방사성폐기물의 심지층처분 연구의 일환으로 한국원자력연구원에서 건설된 지하처분연구시설 (KURT, 이 하 KURT)을 대상으로 심부 지질환경 특성을 정량적으로 평 가한 연구 결과에 대한 내용이며, 기존의 연구 결과[1]에 KURT 내 굴착한 심부 시추공 (DB-1, 심도 500m)에서 획득 한 결과[2]와 KURT 건설 과정에서 획득된 단열 조사 결과를 종합한 지질모델을 제시하고, 지질모델을 구성하는 지질요
소 (geological element)에 대한 수리특성을 제시하여 수리 지질모델을 구축하고자 하였다.

본 논문은 2012년 4월 IAEA WATRP (Waste Management Assessment \& Technical Review Program)의 심층 검토를 위해 작성되었으며, 그 결과는 A-KRS (Advanced Korea Repository System) 개발을 위해 KURT 지역을 가상의 처분 장으로 하여 평가한 지하수 유동 모델링에 직접 입력되어 처 분장의 안전성이 평가되었음을 밝혀둔다.

\section{II. 연구지역}

연구지역의 지형 및 지질, 규모 정의와 연구에 이용된 시추 공에 대해서 박경우 등[1]내용을 요약하여 다음과 같이 기술 하였다.

\section{가. 연구지역의 지형 및 지질}

연구지역을 광역적으로 보면 서쪽으로는 가장 높은 계룡산 이 존재하고 계룡산 줄기를 능선으로 공주시와 접하며, 갑천 이 서남쪽에서 북동쪽으로 흐른다. 연구지역은 경기변성암 복합체 내에 위치하며 주로 선캄브리아기의 편마암류와 중생 대의 심성암과 맥암류로 구성되어 있다 (Fig. 1). 선캄브리아 기의 변성암류는 연구지역의 북서부에 분포하고, 심성암류는 크게 시대 미상의 편상화강암과 연구지역 전범위에 걸쳐 광 범위하게 분포하는 복운모화강암으로 나뉜다. 이 중 복운모 화강암이 편상화강암을 관입하고 있는 것으로 알려져 있다. 연구지역 외곽부에는 중생대 심성암류가 시대미상의 변성퇴 적암류를 관입하고 있다[3]. 4 기 충적층이 수계를 따라 3 11

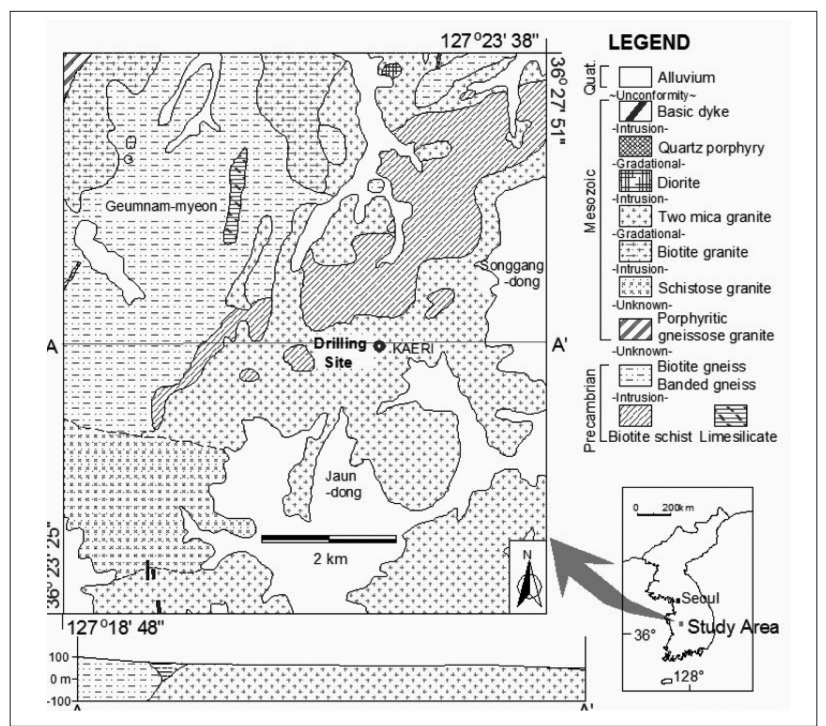

Fig. 1. Geologic map of the study area[1]. Study area is located in the northern part of Daejeon. 
$\mathrm{m}$ 의 두께를 보이면서 매우 광범위하게 분포하고 있다 (Fig. 1)[4].

\section{나. 연구지역의 규모 정의}

일반적으로 연구지역의 규모를 정의할 때에는 지하수의 유 동 양상에 근거하여 모델 영역을 광역, 국지, 부지, 암반블록 으로 분류한다 (Fig. 2)[5]. 본 연구에서는 선형구조 분석이 수 행된 국지 규모 영역과 지구물리탐사 및 연구용 시추공이 굴 착된 부지 규모의 영역을 이용하였다. 국지 규모의 영역을 설 정하기 위하여 광역 규모의 지하수 유동 모델링을 통해 연구 지역의 무유량 경계의 영역을 이용하였으며, 부지 규모는 국 지 규모의 한 부분으로 연구지역에 대한 상세 현장 조사가 수 행되었던 부분을 포함하여 구성하였다 (Fig. 3).

\section{다. 시추공의 위치}

방사성폐기물 처분을 위한 심부지질환경 특성 연구의 일환 으로 한국원자력연구원내 부지에 16 개의 시추공을 굴착하였 다. 시추공의 위치 및 굴착심도에 따라 $\mathrm{BH}$ 와 $\mathrm{YS}, \mathrm{KP}$ 관정군 및 $\mathrm{DB}$ 관정으로 분류하였는데, $\mathrm{BH}$ 관정군 $(\mathrm{BH}-2, \mathrm{BH}-3$, $\mathrm{BH}-4, \mathrm{BH}-5, \mathrm{BH}-6)$ 은 천부 지하수의 수리특성 조사를 위해 지하 $100 \mathrm{~m}$ 이내의 깊이로 굴착되었고, YS 관정군 (YS-1, YS2, YS-3, YS-4, YS-5, YS-6, YS-7)은 심부 지질 특성 및 심부

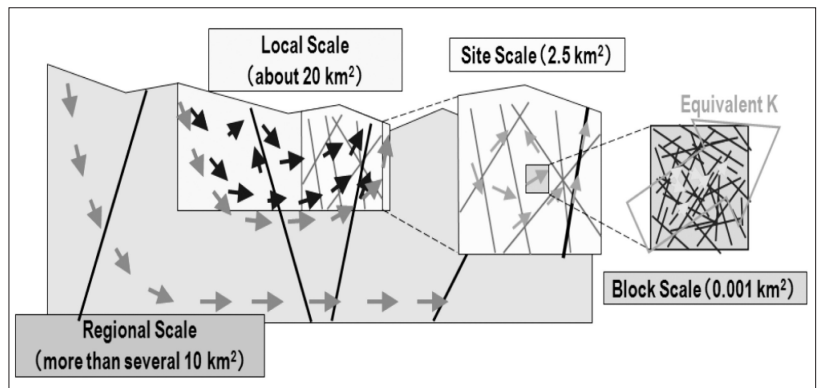

Fig. 2. Schematic diagram showing groundwater flow at each spatial scale around the KURT area[6].

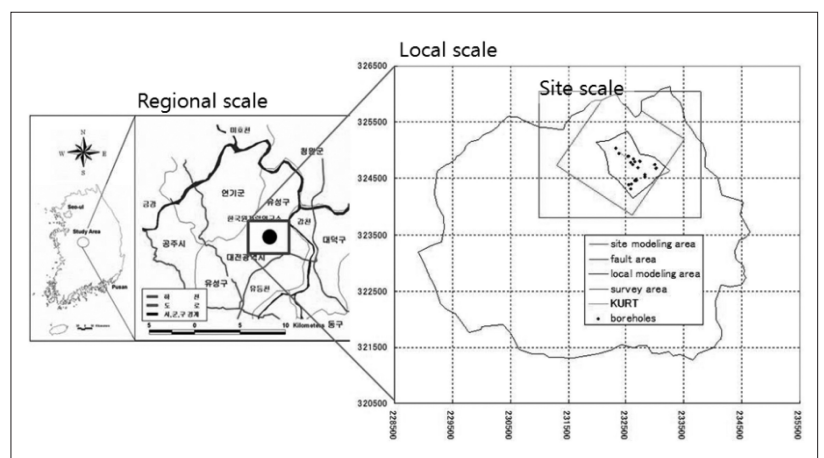

Fig. 3. Areal scale of the study area. Local scale area was selected based on the groundwater dividing line in underground.
지하수의 수리특성 조사를 위해 지하 200 500 m의 깊이로 굴착되었다[6]. 또한, KURT가 건설되기 전 부지 조사를 위하 여 KURT 입구에 수직 방향으로 KP-2시추공을 굴착하였으며, 평행한 방향으로 $\mathrm{KP}-1$ 시추공을 굴착하였다. 이외에 지하처분 연구시설 내부에 처분 대상 심도 이상 $(500 \mathrm{~m}$ 이상 $)$ 의 지하에 대한 지질, 수리지질 및 지화학 특성을 파악하기 위해 장심도 시추공인 DB-1 (심도 $500 \mathrm{~m}$ )와 DB-2 (심도 1,000 m)시추공 을 2008년과 2009년에 각각 굴착하였다 (Fig. 4).

기존의 연구는 KURT 주변 지역의 시추공을 대상으로 시추 공 초음파주사검층 자료가 확보된 9개의 시추공을 대상으로 수행하였으며, 본 연구는 기존의 9개의 시추공과 더불어 장심 도 시추공 자료를 포함하여 작성하였다 (Table 1).

\section{III. 연구지역}

KURT의 지질모델 구축을 위해 지표에서 수행 가능한 물리 탐사, 선형구조 분석의 간접적인 방법과 시추공과 터널에서

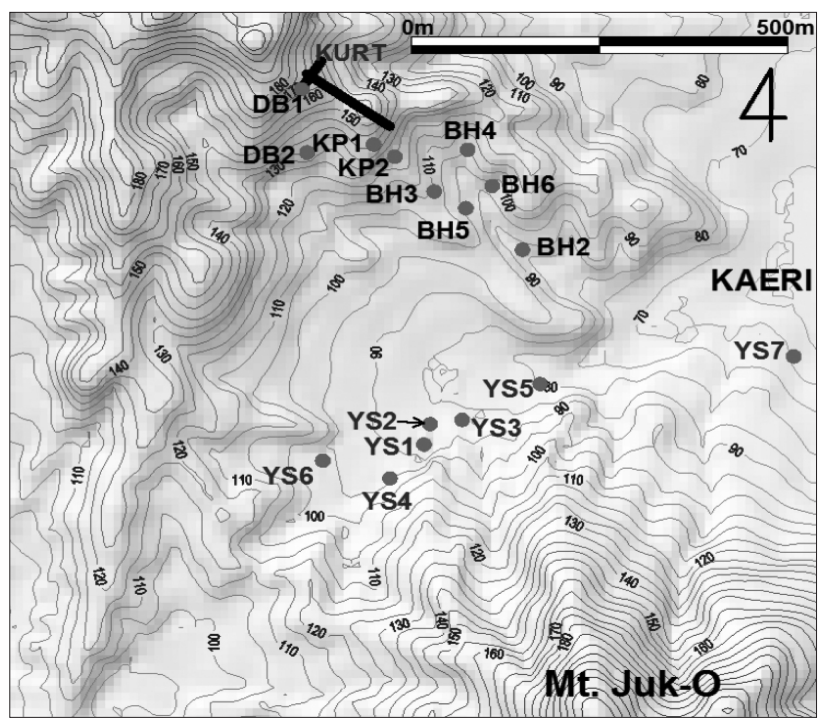

Fig. 4. Locations map of the boreholes. Total 16 boreholes were drilled at the study area and grouped into 4 well fields (YS, BH, KP, DB well fields). In this study, YS-1 $\sim$ YS-7 borehole, KP-1, 2 and DB-1, 2 borehole data were used for construction of geological model.

Table 1. Information of borehole specifications.

\begin{tabular}{|c|c|c|c|}
\hline Borehole & Drill depth $(\mathrm{m})$ & Orientation (trend/plunge) & Borehole top elevation $(\mathrm{m})$ \\
\hline YS-1 & 500 & Vertical & 82 \\
\hline YS-2 & 200 & Vertical & 81 \\
\hline YS-3 & 300 & Vertical & 81 \\
\hline YS-4 & 350 & Vertical & 81 \\
\hline YS-5 & 200 & $360 / 80$ & 80 \\
\hline YS-6 & 500 & $150 / 80$ & 94 \\
\hline YS-7 & 400 & $340 / 80$ & 56 \\
\hline KP-1 & 252 & $304 / 5.7$ & 116 \\
\hline KP-2 & 160 & Vertical & 115 \\
\hline DB-1 & 500 & Vertical & 114 \\
\hline DB-2 & 1,000 & Vertical & \\
\hline
\end{tabular}


단열을 조사하는 직접적 방법을 이용하였으며, 최종적으로 모든 결과를 종합하여 지질모델을 완성하였다.

선형구조 분석에서는 연구지역의 지하수 시스템을 고려하 여 국지영역과 부지영역으로 구분하여 실시하였으며, 각 영 역에서 수치지형도의 고도 자료를 이용하여 과거의 지형을 임의로 재현하는 접봉도면 (summit level map)을 작성한 후 선형구조 분석을 수행하였다 (Fig. 5). 그리고 지하처분연구 시설 주변 지역의 부지 규모에 대한 지질구조를 간접적으로 예측하기 위해 전기비저항 탐사, 굴절법/반사법 탄성파 탐사 와 시추공을 이용한 multi-shot VSP 탐사를 이용하였으며 총 16 개의 측선 (총 연장길이 $6,445 \mathrm{~m}$ )에서 지표 지구물리탐사 를 수행하였다 (Fig. 6)[7],[1].

심부 지하 환경을 직접 조사하기 위해 시추공 조사와 터널 조사를 수행하였다. 시추공 조사로서 연구지역에 장심도 시 추공을 포함한 16 개의 시추공을 굴착하였으며, 이 중 11 개 시 추공에서 초음파 주사검층을 수행하였다. 또한, 다중패커시 스템이 설치되지 않은 수직 경사의 시추공에서 시추공 지구 물리검층을 수행하여 지하에서 발견할 수 있는 주요 지질구 조를 분석하였다. KURT 건설 과정에서 획득된 단열조사 자 료도 지질모델 구축에 활용하였다 (Fig. 7). 터널 내 단열조사 의 일환으로 건설 중 막장 전면에서 단열 조사를 수행하였는 데, 본 논문에서는 터널을 가로지르는 단열만을 대상으로 분 석한 자료를 이용하였다.

KURT 지역에서 구축된 지질모델의 요소들에 대한 수리지 질특성을 도출하기 위해 이중패커를 이용하여 일정 구간별 정압주입시험 (KURT 외부 시추공)과 예측된 단열대 및 암반

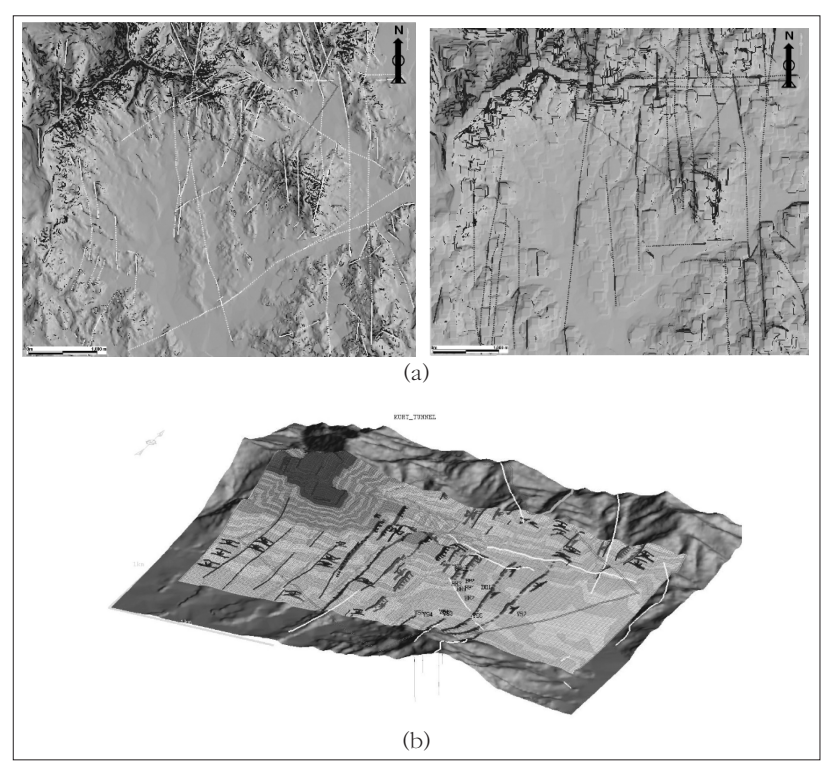

Fig. 5. Results of lineament analysis in local scale(a) and site scale(b) area[1].
영역에 대한 정압배출시험 (KURT 내부 시추공)을 수행하였 다. KURT 외부 시추공에서 수행한 일정 구간별 정압주입시 험 결과를 이용하여 토양층을 포함한 상부 풍화대의 수리지

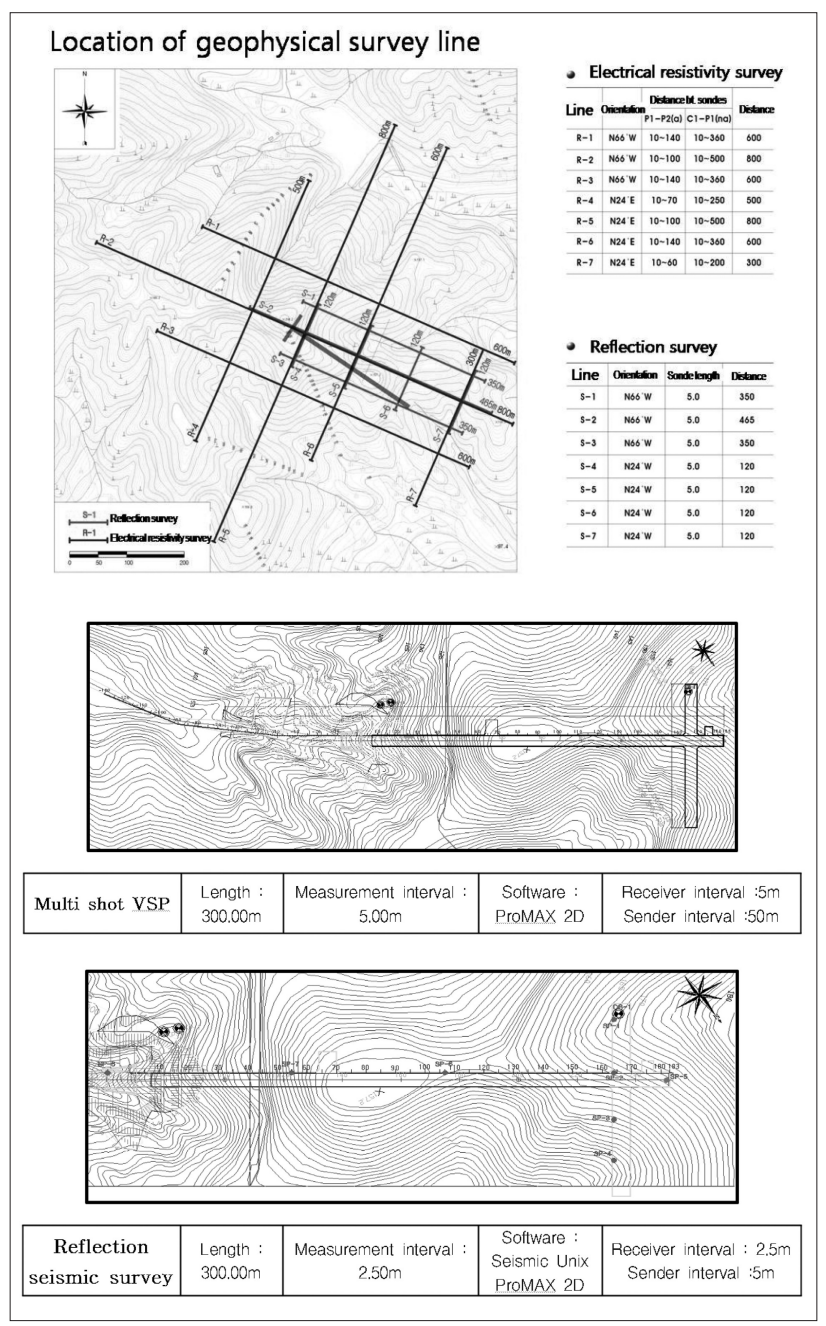

Fig. 6. Surface geophysical survey around KURT area.

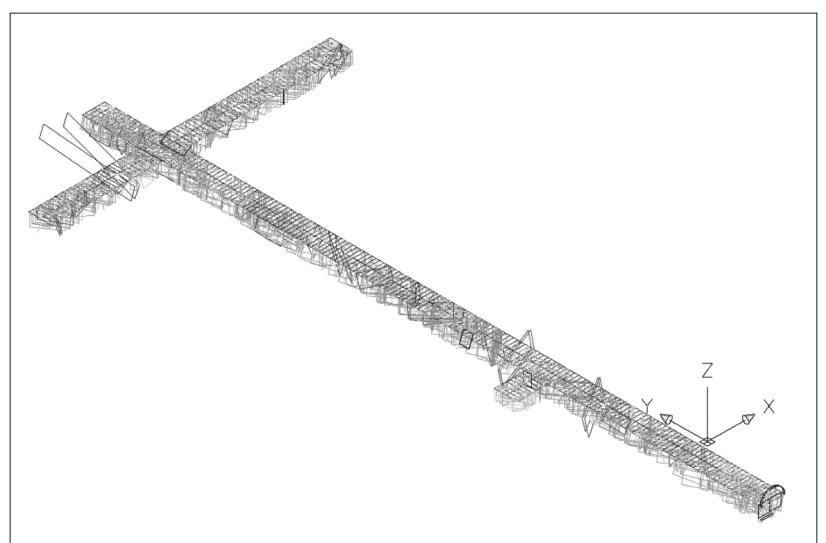

Fig. 7. Three dimensional fracture map of KURT facility. 
질 특성을 도출하였으며, 시추공 단열조사에서 예측된 단열 구간을 구분하여 단열대와 암반 영역의 수리특성을 도출하였 다. KURT 내부 시추공에서는 정압배출시험을 실시하였는데, 단열대 영역과 암반 영역을 구분하여 현장 수리시험을 수행 하였다 [6],[8],[9].

\section{IV. 연구 결과}

\section{가. 지질모델}

KURT 주변 지역의 지질모델 요소는 상부 토양층 및 풍화 대, 그 하부에 존재하는 고투수성 저경사 단열대, 기반암과 기반암에 존재하는 단열대로 구분할 수 있다. 이를 암질모 델 (lithological model)과 지질구조모델 (geo-structural model)로 구분하여 KURT의 지질모델로서 다음과 같이 제 시하였다.

\section{(1) 암질 모델 (lithological model)}

KURT 주변 지역의 암질 모델은 상부 토양층 및 풍화대 (weathered rock, WR), 저경사 단열을 포함하는 상부의 단 열이 발달된 암반대 (upper highly fractured rock, UHFR), 하부 기반암 (lower sparsely fractured rock, LSFR)으로 구 분할 수 있다.

상부 토양층 및 풍화대에 대한 정보는 지표 지구물리탐사 와 시추공 검층자료를 통해 분석되었다. 지표 지구물리탐사 결과 중 심도에 따른 전기비저항 탐사 결과는 상부 풍화대 의 깊이까지 저비저항치를 나타내어 공간적인 상부 토양층 및 풍화대의 분포를 제시하였으며, 이를 시추공의 코아 검 층 결과와 시추공 텔레뷰어 결과와 비교 분석하여 그 깊이 분포를 확인하였다 (Fig. 8).

KURT 주변 지역에 굴착한 시추공 단열 조사 결과, 토양 층 및 풍화대 하부에 존재하는 암반에서 단열 빈도가 보다 깊은 영역에 비해 상대적으로 크고, 저경사 (low angle) 방 향의 단열이 우세하게 분포하는 영역을 확인할 수 있었다 [1]. 저경사 방향의 단열이 우세하게 분포하는 영역은 KURT 내부에 굴착된 조사용 시추공을 제외한 각 시추공에서 공통 적으로 확인되었으며, 따라서 이를 KURT 암질 모델의 한 요소로 고려하였다. 저경사 단열이 우세하게 분포하는 영역 은 지구물리탐사 중 전기비저항 탐사 결과에서도 확인이 가 능하였는데, 상부 풍화대에 비해서는 그 저항치가 높지만 하부 기반암보다는 현저히 저항치가 낮게 분포하는 영역과 일치하였으며, 본 암질모델에서는 그 깊이를 상부의 단열이 발달된 암반영역 (UHFR)이라고 정의하였다 (Fig. 9).

본 연구지역의 지질은 중생대의 복운모화강암으로 구성
되어 있다. 일반적으로 화강암의 수리지질학적으로 매우 낮 은 투수성을 가져, 어떤 경우에는 지하수가 전혀 통과하지 않는 불투수영역으로도 고려되기도 한다. 즉, 화강암 내에 지하수가 통과할 수 있는 단열이 발달되지 않거나, 그 빈도 가 극히 낮은 영역을 상부의 단열이 발달된 암반 영역과 구 분하여 암질 모델을 구성할 수 있다. 본 연구지역에서는 시 추공에서 단열의 빈도를 기준으로 상부의 단열이 발달된 영 역과는 별개로 하부의 단열이 극히 발달하지 않는 암반 (LSFR)을 따로 구분하여 암질모델의 한 요소로서 정의하였 다.

\section{(2) 지질구조 모델 (geo-structural model)}

일반적으로 "단열 (fracture)" 은 지각의 움직임, 지진, 화 산 활동 등 조구조적 기작이나 암반 내 존재하는 구성 물질 의 변형 및 기타 이물질의 침투에 의해 암반 내에 생성된다. 특히, 지하 깊은 심도에 존재하는 단열의 경우 주로 조구조 적 움직임에 의해 생성되는데, 따라서 단열의 방향성은 그 단열이 존재하는 영역에서 응력의 방향성의 지시자가 되는 것이다. 수리지질학적 관점에서 단열은 단열대를 형성하여 지하수가 암반사이로 흐를 수 있게 하는 유동로 역할을 하 게 된다. 그 결과, 공간적으로 이격되어 존재하는 화학 성분 이 상이한 지하수가 혼합될 수도 있어 단열은 지하수 화학 적 관점에서도 매우 중요하다. 이른 바, 지질 매체 내에 존재 하는 지질구조인 단열은 심부 지질, 지하수의 유동 특성 및 화학 특성, 역학적 특성을 이해하는데 가장 기본적인 요소 가 되는 것이다.

연구지역의 시추공에서 확인되는 단열의 통계 분석 결과 각 시추공별로 단열대를 도출하였으며, 이를 지표 지구물리 탐사 결과와 선형구조 분석 결과를 비교하여 결정론적으로 구분할 수 있는 총 10 개의 단열대를 도출하였다. 최종 도출 된 10 개의 단열대에 대해 시추코아 조사 결과를 이용하여 주단열 (major fracture)을 분석하였으며, 단열대 코아 (core) 및 주단열에 대한 단열 손상대 (damaged zone)에 대 한 크기 시추공텔레뷰어의 결과를 기준으로 분석하였다 (Table 2).

일반적으로 배경 단열을 제외한 단열대는 길이 및 폭을 기준으로 regional scale의 단열대과 local scale의 단열대로 나눌 수 있다. Local scale의 단열대를 다시 세분하여 Local major 단열대와 local 단열대로 구분하는데[10], 위에서 분 석된 KURT 연구지역의 단열대는 박경우 등이 제시한 본 연 구지역에서 기존의 연구에 따른 분류체계를 인용하도록 한 다(Table 3)[1]. 이는 연구지역의 단열대의 길이가 local scale의 규모에 국한되고, 기존 분류체계에 따른 local scale 


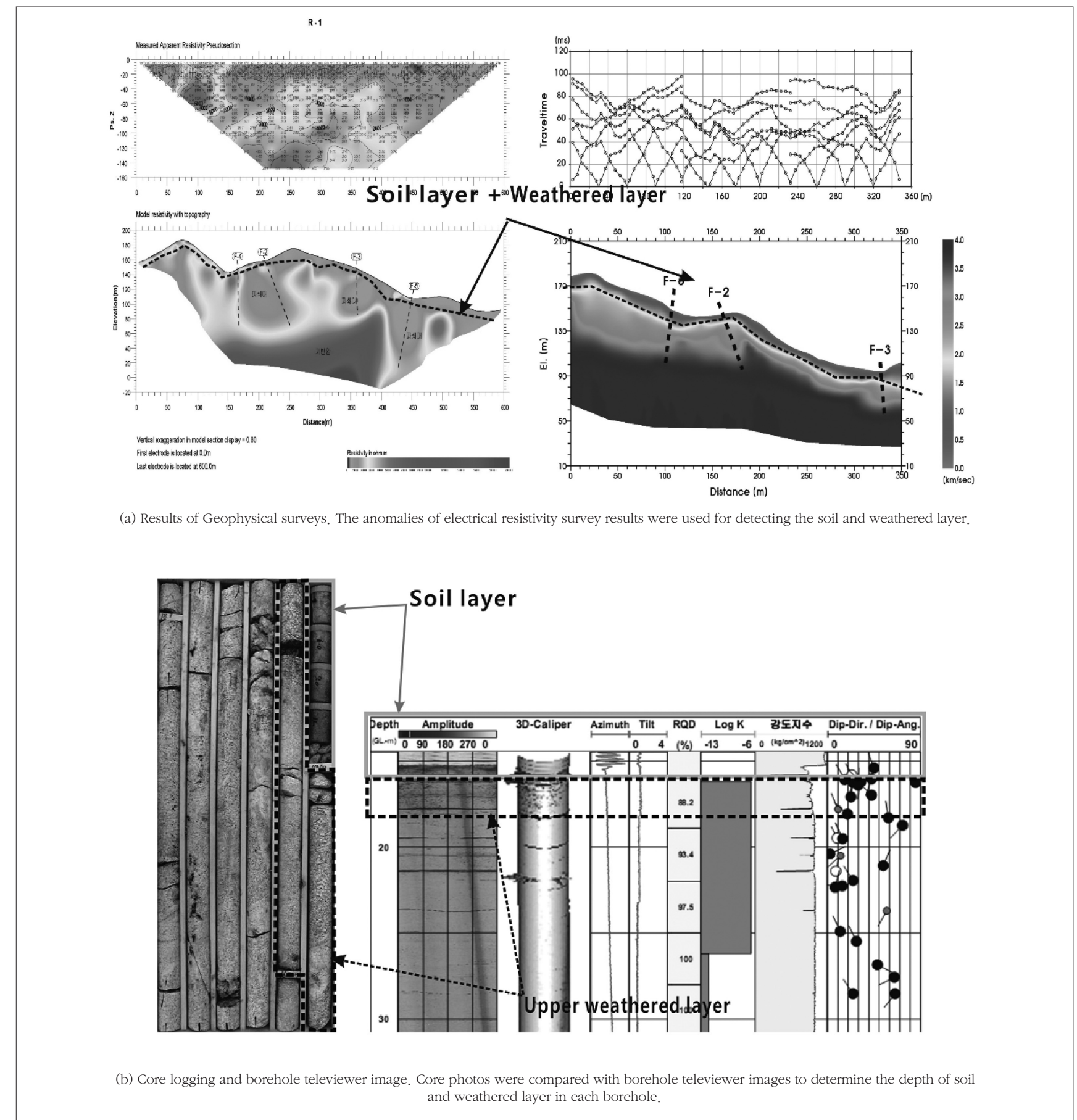

Fig. 8. Methodology to confirm the weathered zone in the study area.

의 단열대 분류의 폭에 대한 범위가 커서 상세한 분류를 어 렵게 하기 때문이다. 또한, 이 분류 결과를 단열대의 수리지 질모델에서 단열대의 크기에 따른 수리특성 분류 기준으로 활용하고자 하기 때문에 local scale의 규모에 대해 보다 상 세한 분류를 고려하였다.

단열대의 분류 기준에 따라 KURT 주변 연구지역에서 심부
영역에 존재하는 단열대에 대해 다음과 같이 분류하여 보았 다. 분류된 단열대 명칭은 ${ }^{\circledR} F Z(o r d e r)$ (분류결과)-No.』의 순서 와 형식으로 정하였다 (Table 4). 연구지역에 존재하는 단열대 는 FZ2A 규모가 총 7개가 존재하며, FZ2S 단열대 2개, FZ2B 단열대가 1 개가 분포하는 것으로 분석된다. 이에 대한 명칭은 향후 추가적인 현장조사 결과에 따라 일부 변경될 수 있다. 


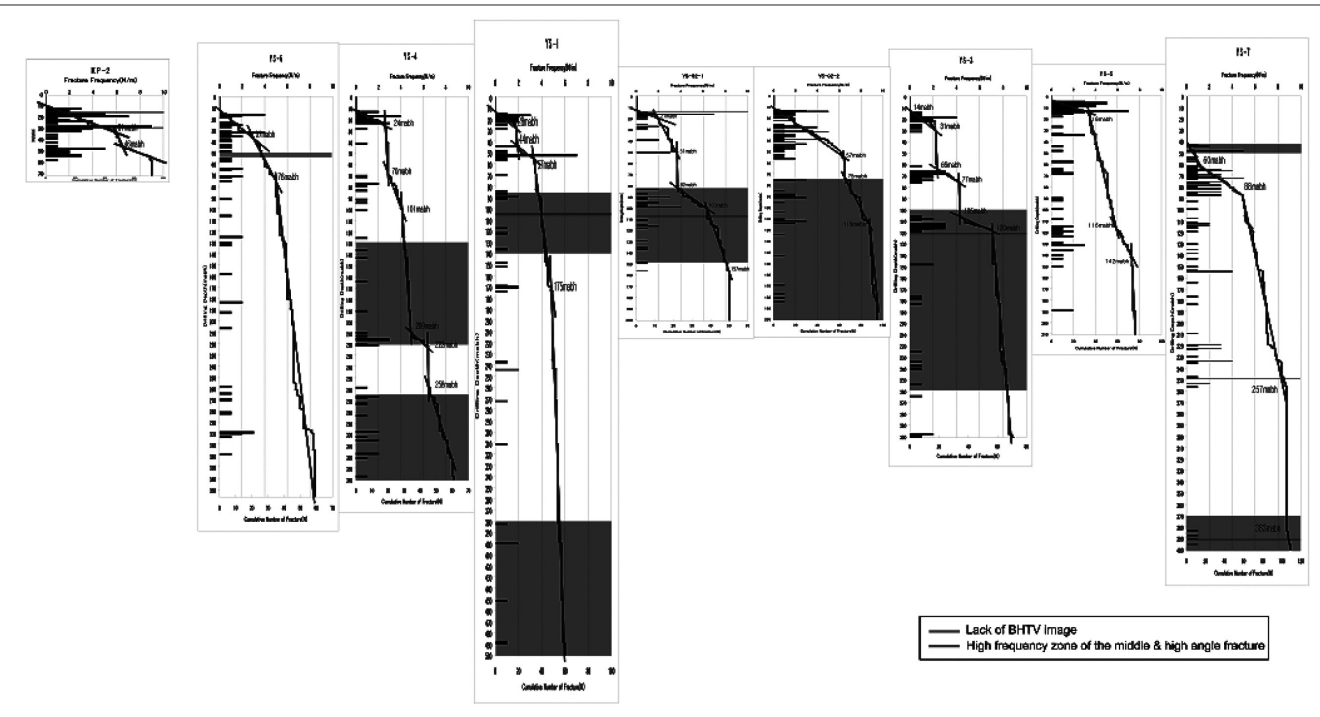

Low-angle fracture frequency $(\mathrm{D}=<30$ degree)

(a) Borehole televiewer image to identify depth of upper highly fractured rock including low-angle fractures.
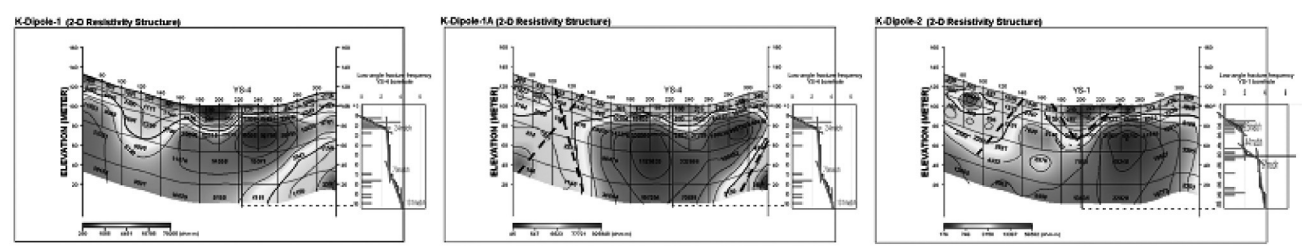

(b) Results of Geophysical surveys. The anomalies of electrical resistivity survey results were used for detecting depth of upper highly fractured rock including low-angle fractures.

Fig. 9. Methodology to confirm the upper highly fractured rock in the study area.

\section{나. 지질모델 요소의 수리지질특성}

KURT 주변 지역의 지질모델 요소에 대응된 수리지질모 델의 수리적 특성을 판단하기 위해 먼저 지질모델요소에 대 응하는 수리지질특성을 개념화하였고, 각 요소의 투수특성 을 정규성 검정을 이용하여 수리전도도가 갖는 평균을 제시 하였다.

KURT 주변 지역의 지질모델은 앞 장에서 기술한 바와 같 이 상부 토양층을 포함한 풍화대, 상부 단열밀도가 높은 암 반영역, 하부의 단열밀도가 낮은 암반 영역으로 그 암질에 따라 분류가 가능하며, 암반영역에 존재하는 단열대를 지질 구조모델에서 제시하였다. 이들 각 요소가 갖는 수리지질특 성을 개념화하면 상부 토양층을 포함한 풍화대 영역은 수리 토양영역 (hydraulic soil domain, HSD)으로 구분할 수 있 으며, 암반 영역 중 저경사 단열을 많이 포함하고 있으며 단 열 밀도가 높은 암반 영역에 대해서는 저경사 단열영역 (low angle fractured domain, LAFD)으로, 하부의 단열밀
도가 낮은 암반영역의 경우 수리암반영역 (hydraulic rock domain, $\mathrm{HRD}$ )로, 마지막으로 기반암 내에 존재하는 단열 대를 수리투수영역 (hydraulic conductor domain, HCD)로 구분할 수 있다. 이에 대한 수리지질학적 개념 특성을 Table 5 에 제시하였다.

수리지질모델에서 수리토양영역의 수리전도도의 분포는 수리시험 결과에 대한 자료가 충분하지 않아 일부 시추공에 서 산출된 수리전도도 $\left(1.50 \times 10^{-7} \mathrm{~m} / \mathrm{sec}\right)$ 를 이용하였다. 저 경사 단열영역의 경우, $1.05 \times 10^{-7} \mathrm{~m} / \mathrm{sec}$ 의 평균값 (표준편 차를 이용한 분포 : $10^{-7.76} \sim 10^{-6.24} \mathrm{~m} / \mathrm{sec}$ )을 보이며, 비교 적 작은 표준편차를 갖고 있다. 심부 영역에 존재하는 기반 암의 경우, 평균 $4.36 \times 10^{-10} \mathrm{~m} / \mathrm{sec}$ (표준편차를 이용한 분 포 : $10^{-11.23} \sim 10^{-8.79} \mathrm{~m} / \mathrm{sec}$ )의 저경사 단열영역에 비해 현 저히 낮은 값으로 산출된다 (Table 6)[6].

지질구조모델에서 제시된 단열대의 투수량계수는 다음 Table 7과 같다. Local major 규모로 분류된 FZ2S-1과 FZ2S- 
Table 2. Fracture zones from field investigations. Fractures obtained by borehole televiewer were used to identify the width of damaged zone.

(mabh:meter along borehole)

\begin{tabular}{|c|c|c|}
\hline \multicolumn{2}{|c|}{ Fracture zone } & Data source \\
\hline \multirow[t]{2}{*}{1} & YS1_104F & $\begin{array}{l}\text { Fracture survey (BHTV, core logging) } \\
\text { Lineament analysis }\end{array}$ \\
\hline & YS1_104DZ & BHTV (87.2-138.0mabh) \\
\hline \multirow[t]{2}{*}{2} & YS1_433F & $\begin{array}{l}\text { Fracture survey (BHTV, core logging) } \\
\text { Geophysical survey (Resistivity) } \\
\text { Lineament analysis }\end{array}$ \\
\hline & YS1_433DZ & BHTV (417.3-447.2mabh) \\
\hline \multirow[t]{2}{*}{3} & YS2_106F & $\begin{array}{l}\text { Fracture survey (BHTV, core logging) } \\
\text { Geophysical survey (Resistivity) } \\
\text { Geophysical logging (Caliper, SP) } \\
\text { Lineament analysis }\end{array}$ \\
\hline & YS2_106DZ & BHTV (88.9-152.1mabh) \\
\hline \multirow[t]{2}{*}{4} & YS6_70F & $\begin{array}{l}\text { Fracture survey (BHTV, core logging) } \\
\text { Geophysical survey (Resistivity) } \\
\text { Geophyscial logging (EC. Temp.) } \\
\text { Lineament analysis }\end{array}$ \\
\hline & YS6_70DZ & BHTV (51.5-93.0mabh) \\
\hline \multirow[t]{2}{*}{5} & KP1_75F & $\begin{array}{l}\text { Fracture survey (BHTV, core logging) } \\
\text { Lineament analysis }\end{array}$ \\
\hline & KP1_75DZ & BHTV (27.0-83.0mabh) \\
\hline \multirow[t]{2}{*}{6} & KP1_120F & $\begin{array}{l}\text { Fracture survey (BHTV, core logging) } \\
\text { Tunnel fracture survey } \\
\text { Lineament analysis }\end{array}$ \\
\hline & KP1_120DZ & BHTV (115.0-132.0mabh) \\
\hline \multirow[t]{2}{*}{7} & KP1_177F & $\begin{array}{l}\text { Fracture survey (BHTV, core logging) } \\
\text { Tunnel fracture survey } \\
\text { Geophysical survey (Resistivity) }\end{array}$ \\
\hline & KP1_177DZ & BHTV (176.5-181.6mabh) \\
\hline \multirow[t]{2}{*}{8} & DB1_213F & $\begin{array}{l}\text { Fracture survey (BHTV, core logging) } \\
\text { Geophyscial logging (all) } \\
\text { lineament analysis }\end{array}$ \\
\hline & DB1_213DZ & BHTV (201.5-226 mabh) \\
\hline \multirow[t]{2}{*}{9} & DB1_241F & $\begin{array}{l}\text { Fracture survey (BHTV, core logging) } \\
\text { lineament analysis } \\
\text { Geophyscial logging (all) } \\
\text { BHTV (YS-7 borehole) }\end{array}$ \\
\hline & DB1_241DZ & BHTV (234-244 mabh) \\
\hline 10 & L1 & $\begin{array}{l}\text { lineament analysis } \\
\text { Geophysical survey (Resistivity) }\end{array}$ \\
\hline
\end{tabular}

Table 3. Criteria of fracture zone size classification (KURT area).

\begin{tabular}{|c|c|c|c|c|}
\hline Class (SKB) & $\begin{array}{c}\text { Sub-class } \\
\text { (KURT) }\end{array}$ & Width & $\begin{array}{l}\text { Geometric } \\
\text { description }\end{array}$ & $\begin{array}{l}\text { Order } \\
\text { (SKB) }\end{array}$ \\
\hline $\begin{array}{c}\text { Regional fracture } \\
\text { zone }\end{array}$ & & $>100 \mathrm{~m}$ & Deterministic & Order 1 \\
\hline \multirow{3}{*}{$\begin{array}{l}\text { Local major } \\
\text { fracture zone }\end{array}$} & Class S & $50-100 \mathrm{~m}$ & \multirow{3}{*}{$\begin{array}{c}\text { Deterministic } \\
\text { (with uncertainties) }\end{array}$} & \multirow{3}{*}{ Order 2} \\
\hline & Class A & $10-50 \mathrm{~m}$ & & \\
\hline & Class B & $5-10 \mathrm{~m}$ & & \\
\hline Local fracture zone & Class C & $0.1-5 \mathrm{~m}$ & $\begin{array}{c}\text { Statistical } \\
\text { (somewhat } \\
\text { deterministic) }\end{array}$ & Order 3 \\
\hline Background Fracture & & $\langle 0.1 \mathrm{~m}$ & Statistical & Order 4 \\
\hline
\end{tabular}

2 단열대의 경우 $2.09 \times 10^{-5} \mathrm{~m}^{2} / \mathrm{sec}$ 와 $2.18 \times 10^{-5} \mathrm{~m}^{2} / \mathrm{sec}$ 의 투수량계수를 갖는 것으로 산출되어, 다른 단열대에 비해 비교적 큰 값을 갖는 것으로 분석된다. 그러나 FZ2A-7과 FZ2B-1 단열대는 규모가 큰 FZ2S 단열대에 비해 큰 값을 가 져, 단열대의 크기와 단열대가 갖는 투수 특성은 반드시 상 관관계가 없는 것으로 판단된다. 이는 연구지역의 고유 특 성이 아니라 일반적으로 단열이 발달된 결정질 암반에서의 수리지질특성으로, 지질구조모델에서 각각 다른 기하를 갖
Table 4. Classified local major and minor fracture zones at the KURT site.

\begin{tabular}{|c|c|c|c|c|c|}
\hline No & Fracture zone & $\begin{array}{c}\text { Thickness } \\
(\mathrm{m})\end{array}$ & Order & $\begin{array}{c}\text { Classification } \\
\text { result }\end{array}$ & $\begin{array}{c}\text { Name of } \\
\text { fracture zone }\end{array}$ \\
\hline 1 & YS1_104F & 14.0 & 2 & Class A & FZ2A-1 \\
\hline 2 & YS1_433F & 17.3 & 2 & Class A & FZ2A-2 \\
\hline 3 & YS2_106F & 18.5 & 2 & Class A & FZ2A-3 \\
\hline 4 & YS6_70F & 20.1 & 2 & Class A & FZ2A-4 \\
\hline 5 & KP1_75F & 65.9 & 2 & Class S & FZ2S-1 \\
\hline 6 & KP1_120F & 12.5 & 2 & Class A & FZ2A-5 \\
\hline 7 & KP1_177F & 14.0 & 2 & Class A & FZ2A-6 \\
\hline 8 & DB1_213F & 17.3 & 2 & Class A & FZ2A-7 \\
\hline 9 & DB1_241F & 5.6 & 2 & Class B & FZ2B-1 \\
\hline 10 & L1 & - & 1 or 2 & $\begin{array}{c}\text { Class S } \\
\text { (expected) }\end{array}$ & FZ2S-2 \\
\hline
\end{tabular}

Table 5. Conceptual descriptions of hydrogeologic properties of the elements of the geologic model.

\begin{tabular}{|c|c|c|}
\hline \multicolumn{2}{|c|}{ Component } & \multicolumn{2}{c|}{ Hydrogeologic characteristics } \\
\hline Geology & Hydrogeology & \multicolumn{1}{|c|}{ - isotropic permeability } \\
WR & HSD & $\begin{array}{l}\text { - spatially homogeneous or heterogeneous permeable } \\
\text { distribution }\end{array}$ \\
\hline UHFR & LAFD & $\begin{array}{l}\text { - anisotropic permeability } \\
\text { - spatially heterogeneous permeable distribution }\end{array}$ \\
\hline LSFR & HRD & $\begin{array}{l}\text { - isotropic permeability } \\
\text { - spatially homogeneous or heterogeneous permeable } \\
\text { distribution }\end{array}$ \\
\hline FZ & HCD & $\begin{array}{l}\text { - anisotropic permeability } \\
\text { - permeability to be different at each fracture zone }\end{array}$ \\
\hline
\end{tabular}

Table 6. Permeabilities of the components in lithological model for hydrogeological model.

\begin{tabular}{|c|c|}
\hline Components for hydrogeological model & Hydraulic conductivity $(\mathrm{m} / \mathrm{sec})$ \\
\hline HSD & $1.50 \mathrm{E}-07$ \\
\hline LAFD & $1.05 \mathrm{E}-07$ \\
\hline HRD & $4.36 \mathrm{E}-10$ \\
\hline
\end{tabular}

Table 7. Permeabilities of the components in geo-structural model for hydrogeological model.

\begin{tabular}{|c|c|c|}
\hline \multicolumn{2}{|c|}{ Components for hydrogeological model } & Transmissivity $\left(\mathrm{m}^{2} / \mathrm{sec}\right)$ \\
\hline \multirow{4}{*}{} & FZ2S-1 & $2.09 \mathrm{E}-05$ \\
\cline { 2 - 3 } & FZ2S-2 & $2.18 \mathrm{E}-05$ \\
\cline { 2 - 3 } & FZ2A-1 & $3.60 \mathrm{E}-08$ \\
\cline { 2 - 3 } & FZ2A-2 & $2.92 \mathrm{E}-08$ \\
\cline { 2 - 3 } & FZ2A-3 & $1.02 \mathrm{E}-07$ \\
\cline { 2 - 3 } & FZ2A-4 & $1.27 \mathrm{E}-05$ \\
\cline { 2 - 3 } & FZ2A-5 & $5.71 \mathrm{E}-06$ \\
\cline { 2 - 3 } & FZ2A-6 & $1.85 \mathrm{E}-05$ \\
\cline { 2 - 3 } & FZ2A-7 & $1.52 \mathrm{E}-04$ \\
\cline { 2 - 3 } & FZ2B-1 & $4.45 \mathrm{E}-05$ \\
\hline
\end{tabular}

는 단열대를 고려하듯 수리지질모델을 구성할 때에도 각 단 열대의 투수특성이 결정론적으로 수리지질모델에 입력되어 야 함을 의미한다.

\section{V. 결 론}

방사성폐기물 처분연구의 일환으로 한국원자력연구원에 서는 지하처분연구시설 (KURT)를 건설하여 다방면의 연구 를 진행하고 있다. 특히, 부지특성연구의 일환으로 지표 조 
사, 시추공 조사, 터널 조사 등 연구 단계별로 연구지역의 심부환경의 특성을 이해하는 부지특성조사기술의 개발을 위해 다양한 현장시험을 수행하였다.

본 논문에서는 부지특성조사 결과를 바탕으로 KURT 지 역의 지질모델을 암질모델과 지질구조모델로 구분하였으 며, 현장수리시험을 통해 도출한 수리지질특성을 제시하였 다. 이를 요약하면 다음과 같다.

- KURT 주변 지역의 암질 모델은 상부 토양층 및 풍화대 (weathered rock, WR), 저경사 단열을 포함하는 상부의 단열이 발달된 암반대 (upper highly fractured rock, UHFR), 하부의 거의 발달하지 않은 암반대 (lower sparsely fractured rock, LSFR)로 구분할 수 있다.

- 지질구조모델로서 선형구조 분석, 시추공/터널 단열조사, 지표 지구물리탐사, 시추공 지구물리검층 결과를 종합하 여 총 10 개 암반대 내에 존재하는 단열대를 도출하여 지질 구조모델로서 제시하였으며, 각 단열대에 대한 크기를 구 분하여 KURT 지역의 단열대 분류 기준으로 분류하였다.

- 연구지역에서 수행한 현장수리시험 결과 구간별 투수량계 수는 투수성 구조가 존재하는 구간을 제외하고 $10^{-7.5}$ $10^{-11} \mathrm{~m}^{2} / \mathrm{sec}$ 의 범위 화강암 지역에서의 전형적인 값을 보였다.

- 지질모델에서 구분된 토양층 및 풍화대, 상부 단열이 발달 된 암반대, 하부 단열이 발달하지 않은 암반대의 3 개의 암 질모델 요소에 대해 시추공에서 구간별 도출된 투수량계 수를 이용하여 매질의 수리전도도를 산출한 결과, 토양층 및 풍화대의 수리전도도는 $1.50 \times 10^{-7} \mathrm{~m} / \mathrm{sec}$ 의 값을 보였 으며, 상부 단열이 발달된 암반대는 $1.05 \times 10^{-7} \mathrm{~m} / \mathrm{sec}$ 의 평균값으로 산출되었다. 심부 영역에 존재하는 하부 단열 이 발달하지 않은 암반대는 $4.36 \times 10^{-10} \mathrm{~m} / \mathrm{sec}$ 을 보여 현 저히 낮은 값으로 산출되었다.

- 암반영역 내 단열대가 갖는 투수량계수는 $1.50 \times 10^{-4} \sim$ $2.92 \times 10^{-8} \mathrm{~m}^{2} / \mathrm{sec}$ 의 범위를 갖고 있으며 이를 결정론적 으로 제시하였다.

본 논문에서는 기술한 KURT 연구지역의 지질모델과 지 질모델 요소에 대한 수리지질특성은 A-KRS 개발을 위해 KURT 지역을 가상의 처분장으로 고려한 지하수 유동 모델 링에 입력되어 처분 안전성이 평가되었다. 향후 이 연구 결 과는 한국원자력연구원의 연구지역에서 계획된 KURT 확장 과정 중 상세 지질조사 결과를 이용하여 보완될 것이며, 최 종적으로 연구지역의 심부지질환경특성을 보다 잘 설명할
수 있는 모델 개발에 이용하고자 한다. 이처럼 부지특성평 가를 위해 반복, 보완된 연구 결과는 향후 사용후 핵연료의 처분을 위한 부지선정 및 처분장 건설 과정에서 처분의 안 전성 뿐 만 아니라 처분장 건설 안정성 평가에도 직접적으 로 이용할 수 있을 것이다.

\section{References}

[1] Park, K.W., Koh, Y.K., Kim, K.S., Choi, J.W., "Construction of the geological model around KURT area based on the surface investigations", J. of the Korean Radioactive Waste Society, 7(4), pp.191-205 (2009)

[2] Park, K.W., Kim, K.S., Koh, Y.K., Choi, J.W., "Study on the geological structure around KURT using a deep borehole investigation", J. of the Korean Radioactive Waste Society, 8(4), pp.279-291 (2010)

[3] Park, H.I., Lee, J.D., Jung, J.G., Geologic map of Korea (Yuseong area), KIGAM, 21p. (1977).

[4] Jung, J.G., Seo, M.C., Kim, K.S., Hwang, H.J., "Study on the geological structure and geothermal properties around Yuseong area, J. of the Eng. geology in Korea, 7, pp.173-189 (1997).

[5] Sven, F., Roger, T., "On the use of continuum approximations for regional modeling of groundwater flow through crystalline rocks", Advances in Water Resources 17, pp. 133-145 (1994)

[6] Park, K.W., Kim, K.S., Koh, Y.K., Choi, J.W., "Synthetic study on the geological and hydrogeological model around KURT, J. of the Korean Radioactive Waste Society", 9(1), pp.13-21 (2011)

[7] Koh,. Y.K., Bae, D.S., Kim, K.S., Kim, G.Y., Ryu, J.H., Park, K.W., Ji, S.H., Analysis of the seismic reflection survey in the KURT site, KAERI/TR3811-2009, 22pp (2009)

[8] Park, K.W., Bae, D.S., "Analysis of correlation between hydraulic conductivity and fracture characteristics observed by Televiewer logging", J. of the Geological Society of Korea, 41(2), pp.269- 
285 (2005)

[9] Koh,. Y.K., Bae, D.S., Kim, K.S., Kim, G.Y., Ryu, J.H., Park, K.W., Ji, S.H., Choi, J.W., Kim, S.K., Lee, S.Y., Assessment of deep geological environmental condition for HLW disposal in Korea, KAERI/RR-3109-2009, 435pp (2009)

[10] Andersson, J., Berglund, J., Testing the methodology for site descriptive modelling. Application for the Laxemar area. SKB TR-02-19, SKB, Stockholm (2002) 